\title{
PENGARUH STORY-READING (BUKU BILINGUAL) TERHADAP PERKEMBANGAN KECERDASAN LINGUISTIK ANAK USIA DINI
}

\author{
Imaratul Ulwiyah \\ IKIP PGRI Jember \\ ulwiyahimaratul85@gmail.com
}

\begin{abstract}
ABSTRAK
Penelitian ini bertujuan untuk menemukan pengaruh story-reading (membacakan cerita) terhadap perkembangan kecerdasan linguistik anak usia dini, khususnya di TK Al Hikmah Rambipuji-Jember. Jenis penelitian yang digunakan adalah deskriptif kualitatif. Pengumpulan data dilakukan dengan teknik wawancara, observasi dan dokumentasi. Dari hasil penelitian diperoleh bahwa story-reading memberikan beberapa pengaruh positif terhadap peningkatan kecerdasan linguistik yaitu : (1) anak usia dini mengenal dan memahami kosakata baru (2) memahami alur suatu cerita (3) merangkai kata-kata untuk mengukapkan pesan yang tersirat dari suatu cerita. Simpulan, bahwa storyreading dapat memberikan pengaruh terhadap perkembangna kecerdasan linguistik anak usia dini.
\end{abstract}

Kata Kunci: Story-Reading, Linguistik, Anak Usia Dini.

\section{ABSTRACT}

This study aims to find the effect of story reading on the development of early childhood linguistic intelligence, especially in Al Hikmah Rambipuji-Jember Kindergarten. This type of research is descriptive qualitative. Data collection is done by interview, observation and documentation. From the results of the study it was found that storyreading provides several positive influences on improving linguistic intelligence, namely: (1) early childhood know and understand new vocabulary (2) understand the plot of a story (3) compose words to express an implied message of an story. Conclusion, that story-reading can give effect to the development of early childhood linguistic intelligence.

Keywords: Story-Reading, Linguistics, Early Childhood. 


\section{PENDAHULUAN}

Anak usia dini adalah anak yang berumur 0-6 tahun yang memiliki pertumbuhan dan perkembangan yang lebih pesat dan fundamental pada awal-awal tahun kehidupannya. Dimana perkembangan menunjuk pada suatu proses ke arah yang lebih sempurna dan tidak begitu saja dapat diulang kembali. Oleh karena itu, kualitas perkembangan anak di masa depannya, sangat ditentukan oleh stimulasi yang diperolehnya sejak dini. Hal tersebut menjadi penting karena $80 \%$ pertumbuhan otak berkembang pada anak sejak usia dini. Bentuk stimulasi yang diberikan harus dengan cara yang tepat sesuai dengan tingkat perkembangannya (Khadijah:2016).

Selanjutnya Mursid (2015) mengatakan bahwa pada masa usia dini anak mengalami masa keemasan (golden age) dimana anak mulai peka atau sensitif untuk menerima berbagai stimulasi. Stimulasi tersebut akan direspon berbeda oleh setiap anak karena adanya perbedaan laju pertumbuhan dan perkembangan anak secara individual. Masa ini merupakan masa dasar untuk mengembangkan kemampuan kognitif, motorik, bahasa, sosio-emosional, agama dan moral.

Ada beberapa karakteristik anak yang harus dipahami terlebih dahulu karena karakteristik anak usia dini berbeda dengan karakteristik orang dewasa. Yusuf dan Sugandhi dalam Setyorini (2018) memaparkan karakteristik-karakteristik tersebut antara lain: 1)Unik; 2)Egosentris; 3)Aktif dan energik; 4)Rasa ingin tahu yang kuat dan antusias terhadap banyak hal; 5)Eksploratif dan berjiwa petualang; 6)Spontan; 7)Senang dan kaya fantasi; 8)Daya perhatian yang pendek; 9)Masih kurang pertimbangan dalam melakukan sesuatu; 10)Semakin menunjukkan minat terhadap teman.

Anak usia dini merupakan sekelompok individu yang harus mendapatkan pendidikan yang baik dan sesuai demi masa depan anak dan bangsa ini. Pendidikan anak usia dini atau yang sering disingkat PAUD adalah upaya pembinaan yang ditujukan kepada anak sejak lahir sampai dengan usia 6 (enam) tahun yang dilakukan melalui pemberian stimulus pendidikan agar membantu perkembangan dan pertumbuhan baik jasmani dan rohani sehingga anak memiliki kesiapan memasuki pendidikan lebih lanjut (Martinis Yamin \& Jamilah dalam Setyorini:2018).

Pendidkan anak usia dini (PAUD) merupakan wahana pendidikan yang sangat fundamental dalam memberikan kerangka dasar terbentuk dan berkembangnya dasardasar pengetahuan, sikap dan keterampilan pada anak. Keberhasilan proses pendidikan pada masa ini menjadi dasar untuk proses pendidikan selanjutnya dan akan sangat tergantung pada sistem dan proses pendidikan yang diterapkan. Selanjutnya Trianto dalam Setyorini (2018) mengemukakan bahwa PAUD secara khusus memiliki tujuan yaitu, pertama membangun landasan bagi berkembangnya potensi anak agar menjadi manusia beriman dan bertaqwa kepada Tuhan Yang Maha Esa, berakhlak mulia, sehat, berilmu, cakap, kritis, kreatif, inovatif, mandiri, percaya diri, dan menjadi warga negara yang demokratis dan bertanggung jawab. Kedua mengembangkan potensi kecerdasan spiritual, intelektual, emosional dan sosial anak pada masa emas pertumbuhannya dalam lingkungan bermain yang edukatif dan menyenangkan. 
Pendidikan anak usia dini merupakan wahana pendidikan yang tidak terlepas dari permainan karena dunia anak adalah dunia bermain. Menurut Gordon \& Browne dalam Mursid (2015) menyatakan bahwa bermain merupakan pekerjaan masa kanakkanak dan cermin pertumbuhan anak. Bermain merupakan kegiatan yang memberikan kepuasan bagi diri sendiri. Melalui bermain anak memperoleh pembatasan dan memahami kehidupan. Bermain adalah kegiatan yang memberikan kesenangan dan dilaksanakan untuk kegiatan itu sendiri, yang lebih ditekankan pada caranya daripada hasil yang diperoleh dari kegiatan itu. Kegiatan ini juga bersifat santai dan fleksibel.

Dengan bermain anak memperoleh banyak manfaat yang secara tidak langsung dapat memberikan kontribusi besar pada kehidupan masa datang. Beberapa manfaat tersebut seperti menirukan aktivitas orang dewasa yang dapat menambah kosakata baru, membangun hubungan baru dengan individu lain, menyalurkan perasaan yang dirasakan,mencerminkan pertumbuhan sesuai dengan pertambahan usia, dapat memecahkan masalah secara mandiri atau berkelompok dan mencoba berbagai hal baru. Semua manfaat tersebut penting sekali untuk perkembangan kecerdasan mereka karena dengan bermain anak-anak mampu membangun kemampuan yang kompleks. Salah satu hipotesis yang populer dalam psikologi perkembangan bahwa bermain dapat membantu perkembangan kecerdasan.

Selain itu beberapa ilmuan seperti Hetherington, Parke dan Dworetzky dalam Moeslichatoen (1999) menambahkan bahwa fungsi bermain dan interaksi dalam permainan mempunyai peran penting bagi perkembangan kognitif dan sosial anak. Fungsi bermain tidak saja dapat meningkatkan perkembangan kognitif dan sosial, tetapi juga perkembangan bahasa, disiplin, perkembangan moral, kreativitas, dan perkembangan fisik anak.

Bermain bagi AUD bukan hanya sekedar bermain melainkan ada pesan atau suatu pembelajaran yang ingin disampaikan. Pesan yang disampaikan lewat permainan di AUD selalu melibatkan berbagai media sebagai perantaranya atau yang lebih dikenal dengan istilah media pembelajaran. Seperti yang telah dipaparkan di atas bahwa bermain dapat meningkatkan beberapa aspek perkembangan pada AUD. Oleh karena itu, Arsyad dalam '(Khadijah:2016) menyatakan bahwa dalam mengembangkan sebuah media pembelajaran, perlu diperhatikan beberapa prinsip agar media tersebut memberikan pengaruh efektif dalam pencapaian tujuan pembelajaran. Beberapa prinsip yang dimaksud yakni, pertama media yang digunakan harus sesuai dengan tujuan pembelajaran yang telah ditetapkan, kedua media tersebut merupakan media yang dapat dilihat atau didengar, ketiga media yang digunakan dapat merespon siswa belajar, keempat media yang digunakan harus sesuai dengan kondisi individu siswa, kelima media tersebut merupakan perantara (medium) dalam proses pembelajaran siswa.

Membacakan buku cerita atau story-reading merupakan salah satu media pembelajaran yang menarik dan mengundang perhatian anak. Seorang guru harus mampu bercerita dengan ekspresi yang sesuai isi cerita sehingga anak akan tertarik untuk mendengar dan memperhatikan isi cerita yang disampaikan hingga selesai. Menurut Moeslichatoen (2004) beberapa teknik yang bisa dilakukan guru ketika 
membacakan cerita kepada anak-anak yaitu: 1)Membacakannya langsung dari buku cerita; 2)Bercerita dengan menggunakan ilustrasi gambar dari buku; 3)Menceritakan dongeng; 4)Bercerita dengan menggunakan papan flanel; 5)Bercerita dengan menggunakan media boneka; 6)Dramatisasi suatu cerita; 7)Bercerita sambil memainkan jari-jari tangan

Dengan bercerita kepada anak-anak akan diperolah beberapa manfaat antara lain, pertama mengembangkan kemampuan berbicara dan memperkaya kosakata anak. Kedua Mengenalkan beberapa bentuk emosi dan ekspresi kepada anak seperti marah, sedih, gembira, kesal dan lucu. Kedua menstimulasi daya imajinasi dan kreativitas anak, memperkuat daya ingat serta membuka cakrawala pemikiran anak. Ketiga dapat menumbuhkan empati dalam diri anak. Keempat melatih dan mengembangkan kecerdasan anak. Kelima sebagai langkah awal untuk menumbuhkan minat baca anak. Keenam merupakan cara paling baik untuk mendidik tanpa kekerasan, menanamkan nilai moral dan etika juga kebenaran, serta melatih kedisiplinan. Ketujuh membangun hubungan personal dan mempererat ikatan batin orang tua (guru) dengan anak.

Semua manfaat tersebut di atas akan diperoleh secara optimal jika cerita yang dipilih menarik, mudah dipahami, sesuai dengan usia dan daya imajinasi AUD. Selain itu, dengan mendengar suatu cerita baru yang mengandung pesan dan berbagai karakter baru akan memberikan pengaruh besar terhadap kecerdasan linguistik seorang anak. Selanjutnya penelitian ini akan membahas tentang pengaruh story reading terhadap perkembangan kecerdasan linguistik AUD khususnya di TK AL HIKMAH RambipujiJember.

Menurut Gardner (2013), arti dari kecerdasan adalah kemampuan seseorang dalam memecahkan suatu permasalahan yang dihadapi dalam kehidupannya dan mampu menciptakan sesuatu yang bernilai budaya serta bermanfaat bagi masyarakat sekitarnya. Gardner menegaskan bahwa setiap individu pada dasarnya memiliki tujuh jenis kecerdasan yang berbeda-beda dan menggunakannya dengan cara personal tidak klasikal dalam pengembangannya sesuai dengan tumbuh kembang anak. Kecerdasan linguistik merupakan salah satu dari kecerdasan yang dimaksud oleh Gardner.

Kecerdasan linguistik adalah kemampuan berbahasa yang berkembang sesuai dengan tahapannya, muncul dalam bentuk perhatian dan minat seseorang pada hubungan kata-kata, gaya bahasa, olah kata baik lisan maupun tulisan. Manifestasi kecerdasan linguistik bisa dilihat juga pada kemahiran dalam permainan kata-kata di setiap kegiatan dan mengajukan berbagai pertanyaan yang membangun pikirannya dan komunikasi yang efektif.

Kecerdasan linguistik memiliki komponen inti antara lain kepekaan terhadap bunyi, struktur, makna, fungsi kata dan bahasa. Berkaitan dengan kemampuan membaca, menulis, berdiskusi, berargumentasi dan berdebat. Sedangkan kondisi akhir menjadi seorang penulis, wartawan, orator, ahli politik, penyiar radio, presenter, guru, dan pengacara.

Bahasa merupakan bentuk utama dalam mengekspresikan pikiran dan pengetahuan bila anak mengadakan hubungan dengan orang lain. Anak yang sedang 
tumbuh kembang mengkomunikasikan kebutuhan, pikiran, dan perasaan mereka melalui bahasa dengan kata-kata yang mempunyai makna yang unik.

Perkembangan bicara anak itu sendiri untuk menghasilkan bunyi verbal. Kemampuan mendengar dan membuat bunyi-bunyi verbal merupakan hal utama untuk menghasilkan bicara. Kemampuan bicara anak juga akan meningkat melalui pengucapan suku kata yang berbeda-beda dan diucapkan dengan jelas. Pengucapan merupakan faktor penting dalam berbicara dan pemahaman. Kemampuan bicara akan lebih mantap lagi bila anak memberi arti kata-kata baru, menggabungkan kata-kata baru serta memberika pernyataan dan pertanyaan. Semua ini merupakan penggabungan proses berbicara, kreativitas dan berpikir.

Menurut Santrock (2007) dalam pelangi psikologi story-reading atau membacakan cerita merupakan salah satu media yang mewakili karakteristik anak yang memiliki daya imajinasi dan fantasi tinggi. Cerita pada dasarnya memiliki struktur kata dan bahasa yang lengkap serta menyeluruh yang mana di dalamnya sudah terdapat sistem aturan bahasa yang mencakup fonologi (sistem suara), morfologi (aturan untuk mengkombinasikan unit makna minimal), sintaksis (aturan membuat kalimat), semantik (sistem makna), dan pragmatis (aturan penggunaan dalam setting sosial). Dengan storyreading diharapkan anak diharapkan mampu menghasilkan semua suara bahasa, mengenali kata, menambah perbendaharaan kata dan bahkan secara perlahan mampu menghasilkan rangkaian kata yang bermakna.

Seperti telah dijelaskan sebelumnya bahwa bercerita dapat dilakukan dengan berbagai cara. Salah satunya adalah membacakan langsung dari buku. Dengan menerapkan metode ini seorang guru harus memperhatikan beberapa aspek agar membacakan cerita berjalan dengan efektif yaitu mencoba kreatif dan memiliki komunikasi dua arah (guru dan siswa). Selain itu kontak mata dengan pendengar harus diperhatikan agar tercipta interaksi dan membuat pengalaman bercerita menjadi lebih personal.

Buku cerita bilingual adalah buku cerita yang ditulis dalam dua bahasa yaitu bahasa asing (contoh bahasa inggris) dan bahasa indonesia. Buku cerita bilingual terdiri dari dua macam yaitu buku cerita bilingual hasil dari terjemahan dan buku cerita bilingual yang sengaja ditulis langsung dalam dua bahasa oleh si penulis. Dalam penelitian ini buku cerita bilingual hasil terjemahan dipilih karena dirasa keakuratan dari bahasa sumber lebih tepat. Buku ini sengaja dipilih untuk menyampaikan isi atau pesan dari sebuah cerita dan sekaligus mengenalkan beberapa kata asing seperti namanama binatang pada anak-anak.

\section{METODE PENELITIAN}

Penelitian ini menggunakan jenis penelitian kualitatif. Khususnya penelitian kualitatif deskriptif dan terpancang. Disebut deskriptif karena penelitian ini menekankan catatan dengan deskripsi kalimat yang rinci, lengkap, dan mendalam, yang menggambarkan situasi sebenarnya guna mendukung penyajian data (Sutopo, 2006). Kemudian, penelitian ini disebut sebagai penelitian terpancang (embedded research) 
karena sudah menentukan fokus penelitian sebelum masuk ke lapangan studi, (Yin dalam Sutopo, 2006) yaitu ekspresi kemampuan mendengar dan berbicara anak sebagai perwujudan dari kecerdasan linguistik yang diperoleh setelah mendengar cerita.

Sumber data yang digunakan yaitu buku cerita bilingual Erlangga for Kids yang disajikan dalam dua bahasa sekaligus yaitu bahasa Inggris dan bahasa Indonesia. Buku ini dipilih karena menampilkan cerita yang mudah dipahami oleh anak-anak, memiliki pesan moral yang dapat diambil serta visualisasi gambar yang tajam. Selain itu, buku ini sengaja dipilih karena ingin memperkenalkan nama-nama binatang dalam bahasa Inggris khususnya tokoh binatang yang terlibat dalam cerita.

Subjek penelitian ini adalah anak-anak peserta didik di TK Al Hikmah Pecoro Kecamatan Rambipuji Kabupaten Jember. Subjek diambil satu kelas kelompok B.

Teknik pengumpulan data yang digunakan dalam penelitian ini adalah wawancara, observasi dan dokumentasi. Wawancara disini dilakukan dengan sifat terbuka (open-ended), mengarah pada kedalaman informasi serta dilakukan dengan cara yang tidak secara formal terstruktur untuk menjadi dasar bagi penggalian informasi yang lebih lengkap dan mendalam (Sutopo, 2006). Anak-anak akan diberi pertanyaan terkait tokoh dan latar cerita, daya ingat mereka terhadap penamaan tokoh cerita dalam bahasa Inggris serta pesan yang terkandung dalam cerita yang dibacakan. Observasi merupakan suatu proses melihat, mengamati, dan mencermati serta "merekam" perilaku secara sistematis untuk suatu tujuan tertentu. Keseluruhan perilaku dalam proses membaca cerita akan diamati dan direkam. Dokumentasi merupakan suatu cara yang digunakan untuk memperoleh data dan informasi dalam bentuk buku, arsip, dokumen, tulisan angka dan gambar yang berupa laporan serta keterangan yang dapat mendukung penelitian. Dokumentasi digunakan untuk mengumpulkan data kemudian ditelaah. Beberapa catatan hasil dari wawancara dan observasi membaca cerita akan dicatat hasilnya sehingga data dapat ditelaah.

Teknik analisis data penelitian ini mengadaptasi model analisis milik Spradley (1997). Model analisis ini berasumsi bahwa setiap masyarakat mempunyai suatu sistem yang unik dalam mempersepsikan dan mengorganisasikan fenomena dan bahasa sebagai satu-satunya alat untuk memahaminya dan mengungkapkan pemahaman tersebut. Penelitian ini terfokus pada pemahaman anak-anak terhadap suatu cerita yang tercermin melalui pengetahuan mengenai tokoh dan latar cerita serta pesan yang terkandung di dalamnya yaitu buku cerita bilingual berjudul Quiet! (Diam!) dan Here comes the Crocodile (Ini dia si Buaya). Empat langkah analisis tersebut adalah: Analisis domain, dalam tahap ini peneliti melakukan analisis terhadap mana yang termasuk data dan mana yang bukan data. Analisis taksonomi, selanjutnya, peneliti memusatkan perhatian pada domain tertentu yang sangat berguna untuk menggambarkan fenomena atau masalah yang menjadi sasaran studi. Analisis komponen, analisis komponen meliputi hubungan atau keterkaitan antar domain. Menemukan tema-tema (cultural value), didapat setelah dilakukan analisis berulang terhadap domain sehingga peneliti dapat menarik simpulan dan mendapat suatu nilai dari penelitian yang dilakukan. 


\section{HASIL PENELITIAN}

Berdasarkan penelitian yang telah dilakukan sebelumnya bahwa storytelling reading sangat berperan dalam meningkatkan kemampuan menulis, minat membaca dan kecerdasan emosional anak (Wardiah:2017). Dari hasi pnelitian yang dilakukan beberapa temuan yang diperoleh dari analisis disajikan secara sistematis sebagai berikut: Hasil analisis domain, dari sekian banyak buku cerita bilingual untuk anak, dua (2) judul dipilih yaitu Quiet! (Diam!) dan Here comes the Crocodile (Ini dia si Buaya). Kedua buku ini dirasa cukup mewakili fokus dari penelitian untuk mengetahui pengaruh story reading terhadap kecerdasan linguistik anak yang terwujud dalam pengetahuan dan pemahaman tentang tokoh, latar dan pesan yang terkandung dari kedua cerita tersebut. Selain itu, buku bilingual sengaja dipilih agar anak-anak bukan hanya mengenal nama tokoh cerita dalam bahasa Indonesia melainkan juga dalam bahasa Inggris. Hasil analisis taksonomi, kedua buku berjudul Quiet! (Diam!) dan Here comes the Crocodile (Ini dia si Buaya) telah dipilih sebagai sumber data dan domain yang dipilih dari buku tesebut adalah:

Buku pertama yang berjudul Quiet! (Diam!) memiliki tokoh dan latar cerita sebagai berikut:

Tabel 1

Tokoh dalam Buku Quiet!

\begin{tabular}{ll}
\hline Judul buku & Quiet! (Diam!) \\
\hline Tokoh & 1. Pa Lion (Pak Singa) \\
& 2. Baby Leo (Leo, anak singa) \\
& 3. Ma Lion (Bu Singa) \\
& 4. Parrots (Burung Kakaktua) \\
& 5. Hyenas (Hyena, hewan yang memiliki postur dan bentuk \\
& seperti harimau) \\
& 6. Monkeys (Monyet) \\
7. Hippopotamus (Kuda Nil) \\
\hline Latar cerita & Tempat : Hutan (jungle) \\
& Waktu : Siang hari \\
\hline
\end{tabular}

Buku kedua berjudul Here comes the Crocodile (Ini dia si Buaya) memiliki tokoh dan latar cerita sebagai berikut:

Tabel 2

Tokoh dalam Buku Here Comes the Crocodile

\begin{tabular}{ll}
\hline Judul buku & Here comes the Crocodile (Ini dia si Buaya) \\
\hline Tokoh & 1. Crocodile (Buaya) \\
& 2. Monkey (Monyet) \\
& 3. Flamingo (Burung Flaminggo) \\
& 4. Elephant (Gajah) \\
& 5. Zebra (Zebra) \\
\hline Latar & Tempat : hutan hijau (deep green jungle) \\
& Waktu : Siang hari \\
\hline
\end{tabular}


Hasil analisis komponen, analisis komponen dalam penelitian ini terdiri dari dua (2) yaitu analisis komponen pada buku pertama dan analisis komponen pada buku kedua. Analisis komponen pertama yaitu keterkaitan antara anak-anak sebagai subjek penelitian dan buku cerita sebagai domain penelitian. Komponen yang diteliti adalah keterkaitan antara anak-anak dan isi cerita. Kegiatan mendengar, menyimak dan memahami hubungan antar tokoh dan alur cerita ketika buku dibacakan menjadi objek observasi.

Buku kedua yang berjudul Here comes the Crocodile (Ini dia si Buaya) menceritakan hal yang tidak jauh berbeda dengan buku pertama. Disini diceritakan seekor buaya (Crocodile) yang berkeliaran di hutan hijau untuk mencari mangsa. Pertama si Buaya bertemu dengan Monyet (Monkey) dan ingin memangsanya. Namun Monyet tidak kehabisan akal dia berkata "Oh Buaya jangan makan aku. Kalau kamu makan aku maka gigimu yang tajam akan goyah dan patah. Lalu kamu akan menjadi kurus dan kendur seperti kantong kulit. Rahangmu yang kekar akan lemas dan menggelantung. Aku ini si kecil yang menjijikkan". "Aku tahu itu," ucap Buaya sambil berlalu, "Kamu terlalu kecil untuk aku makan". Selanjutnya, beberapa hewan lain seperti Burung Flaminggo (Flamingo), Gajah (Elephant) dan Zebra juga memberikan alasan yang hampir sama agar si Buaya tidak memangsa mereka. Dan pada akhirnya, hewan-hewan lain menawarkan untuk memberikan makanan mereka pada Buaya sehingga mereka hidup rukun dan bercanda tawa bersama.

Hasil analisis tema, dari hasil ketiga analisis di atas yaitu analisis domain, analisis taksonomi dan analisis komponen dapat diambil suatu nilai (cultural value) terhadap penelitian yang telah dilakukan. Pertama, anak-anak memiliki banyak kosakata baru dari cerita yang dibacakan dan mengenal nama hewan dalam dua bahasa sekaligus yaitu bahasa Indonesia dan bahasa Inggris. Kedua, mereka mengerti akan definisi hutan yang mana beberapa anak sebelumnya tidak mengetahui apa yang dimaksud dengan hutan. Ketiga, anak-anak tenang dan antusias mendengar cerita baru yang disajikan melalui gambar yang jelas dan tajam. Setelah cerita selesai dibacakan, Ibu guru menanyakan pesan yang terkandung dibalik cerita dan beberapa dari mereka memberikan jawaban yang saling melengkapi

\section{PEMBAHASAN}

Pada buku pertama berjudul Quiet! (Diam!) cerita diawali oleh suatu kejadian di hutan pada siang hari. Disini ada seekor bayi singa (Baby Leo) yang tidak bisa tidur siang karena semua hewan berisik. Kemudian $\mathrm{Pa}$ Lion (Pak Singa) berteriak 'Diaaaaaam' dan mengancam akan memakan siapa saja yang berisik di hutan dan memyebabkan anaknya terbangun. Dalam sejenak semua hewan terdiam. Namun kemudian, beberapa hewan berisik sehingga $\mathrm{Pa}$ Lion mencoba untuk memangsa mereka tetapi gagal karena dihalangi oleh Ma Lion karena Baby Leo tidak mendengar kegaduhan yang mereka buat. Sehingga pada akhirnya ada suara gemuruh yang menyebabkan Baby Leo terbangun dan Ma Lion langsung menyuruh Pa Lion memangsa hewan yang membuat suara tersebut. Tetapi hal tersebut tidak dapat dilakukan $\mathrm{Pa}$ Lion 
karena suara gemuruh itu berasal dari perutnya sendiri. Semua hewan pun menertawakan $\mathrm{Pa}$ Lion.

Dari isi cerita kedua buku di atas dapat dipetik suatu pesan. Pesan yang terkandung pada buku pertama yaitu kita tidak boleh mencari-cari kesalahan orang lain karena kita juga bisa melakukan suatu kesalahan. Sedangkan, pada buku kedua mengajarkan kepada kita jangan pernah mempunyai niat jahat terhadap teman karena bagaimanapun juga mereka ada ketika kita membutuhkan bantuan atau sedang dalam kesusahan. Dapat ditarik suatu kesimpulan dan paham akan pesan tersebut. Semua nilai tersebut didapat tidak lepas dari penyajian cerita yang didominasi oleh gambar bukan tulisan sehingga isi cerita mudah dipahami.

Story-reading yang telah dilakukan di dalam kelas kelompok B TK Al- Hikmah desa Pecoro kecamatan Rambipuji kabupaten Jember ternyata memberikan beberapa pengaruh positif terhadap kecerdasan linguistik anak yaitu: 1)Mengenal dan memahami kosakata baru; 2)Memahami alur suatu cerita. 3)Merangkai kata-kata bermakna untuk mengungkapkan pesan yang tersirat dari suatu cerita. Ketiga pengaruh tersebut merupakan wujud manifestasi dari kecerdasan linguistik yang bisa dilihat dari kemahiran seseorang dalam mengenal dan memahami kosakata sampai mengolah katakata menjadi bermakna.

\section{SIMPULAN}

Setelah melakukan penelitian ini dapat disimpulkan bahwa dengan story-reading buku bilingual berjudul Quiet! (Diam!) dan Here comes the Crocodile (Ini dia si Buaya) di dalam kelas kelompok B TK Al- Hikmah desa Pecoro kecamatan Rambipuji kabupaten Jember beberapa pengaruh positif terhadap peningkatan kecerdasan linguistik anak diperoleh, yaitu: 1)Mengenal dan memahami kosakata baru baik bahasa Indonesia maupun bahasa Inggris; 2)Memahami alur suatu cerita. 3)Merangkai kata-kata bermakna untuk mengungkapkan pesan yang tersirat dari suatu cerita.

Ketiga pengaruh tersebut merupakan wujud manifestasi dari kecerdasan linguistik yang bisa dilihat dari kemahiran seseorang dalam mengenal dan memahami kosakata sampai mengolah kata-kata menjadi bermakna.

\section{DAFTAR PUSTAKA}

Arsyad, L. (2017). Perkembangan Kecerdasan Linguistik dan Interpersonal AUD Melalui Bermain Peran. Jurnal Parameter. 29(1)

Bright, P \& Parker-Rees, G. (2008). Quiet!:Diam!. London: Little Tiger Press, diterjemahkan di Indonesia oleh penerbit Erlangga.

Gardner, H. (2013). Multiple Intelligences: Kecerdasan Majemuk. Alih bahasa: Alexander Sindoro. Tangerang : Interaksara.

Khadijah. 2016. Pengembangan Kognitif AUD. Medan: Perdana Publishing.

Moeslichatoen, R (2004). Metode Pengajaran di Taman Kanak-kanak. Jakarta: PT. Rineka Cipta.

Setyorini, R. (2018). Peningkatan Kecerdasan Verbal Linguistik AUD melalui Permainan "Gerbong Kata". Jurnal Pendidikan Islam AUD. 01(2). 
Spradley, J., P. (1997). Metode Etnografi. Yogyakarta : PT. Tiara Wacana Yogya.

Sutopo, H., B. (2006). Metode Penelitian Kualitatif. Surakarta : UNS Press

White. K \& Terry, M. (2008). Here Ccomes The Crocodile : Ini Dia Si Buaya. London : Little Tiger Press, diterjemahkan di Indonesia oleh Penerbit Erlangga.

Santrock dalam Metode storytelling Terhadap Kecerdasan Verbal Anak Pra Sekolah https://pelangipsikologi.wordpress.com 